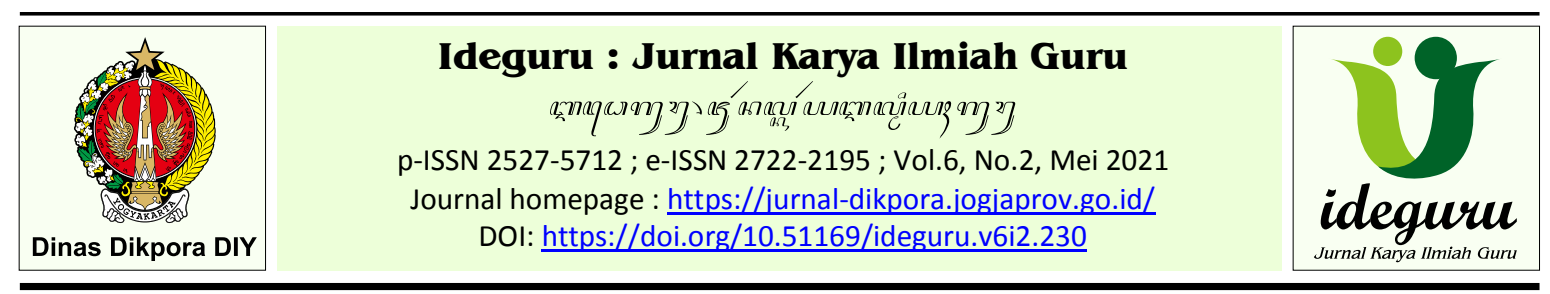

Artikel Penelitian - Naskah dikirim: 06/02/2021 - Selesai revisi: 28/03/2021 - Disetujui: 29/03/2021 - Diterbitkan: 01/05/2021

\title{
Peningkatan Kreativitas dan Hasil Belajar Bisnis Online melalui Metode Demonstrasi
}

\author{
Windu Mahmud \\ SMK Negeri 1 Bantul \\ windu.jogja@gmail.com
}

\begin{abstract}
Abstrak: Penelitian ini bertujuan untuk meningkatkan kreativitas dan hasil belajar Bisnis Online siswa kelas XI BDP 1 SMK N 1 Bantul. Kegiatan penelitian ini termasuk Penelitian Tindakan Kelas (PTK) dengan 2 siklus. Tiap siklus dalam penelitian ini melalui 4 tahapan, yaitu dimulai dari perencanaan, pelaksanaan, observasi dan terakhir adalah refleksi. Subjek dari penelitian Tindakan kelas ini adalah siswa kelas XI BDP 1 SMK N 1 Bantul yang berjumlah 29 siswa pada semester gasal Tahun pelajaran 2019/2020. Teknik pengumpulan data pada kegiatan penelitian ini adalah tes evaluasi dengan tes tertulis, pengamatan/observasi, catatan lapangan dan dokumentasi. Teknik analisa data dalam penelitian ini menggunakan teknik deskriptif kuantitatif. Hasil penelitian ini menunjukkan penerapan metode demonstrasi dapat meningkatkan kreativitas dan hasil belajar siswa kelas XI BDP 1 SMK N 1 Bantul pada mata pelajaran Bisnis Online Tahun Pelajaran 2019/2020. Penerapan metode demonstrasi sesuai dengan rencana pembelajaran dan kreativitas serta hasil belajar siswa meningkat pada tiap siklusnya. Hal ini dibuktikan dengan peningkatan nilai dalam instrument penelitian. Dalam lembar observasi kreativitas belajar siswa diperoleh nilai 48,42 dengan kriteria kurang pada tahap observasi awal. Pada siklus I nilai meningkat jadi 58,55 dengan kriteria cukup dan siklus II diperoleh nilai 67,53 dengan kriteria baik. Selain itu, ketuntasan klasikal pada evaluasi hasil belajar mengalami peningkatan. Pada evaluasi awal ketuntasan klasikal 31,03\%, pada tahap siklus I ketuntasan klasikal naik menjadi $48,28 \%$ dan pada tahap siklus II ketuntasan klasikalnya meningkat menjadi $72,41 \%$.
\end{abstract}

Kata kunci: kreativitas, hasil belajar siswa dan metode demonstrasi

\section{Improving Creativity and Online Business Learning Outcomes through Demonstration Method}

\begin{abstract}
This research aims to increase student creativity and learning outcomes of online business in class XI BDP 1 SMK N 1 Bantul. This research is a Classroom Action Research (CAR) with 2 (two) cycles. Each cycle goes through 4 (four) stages starting from planning, implementing, observing and reflecting. The subjects of this study are 29 students in grade XI BDP 1 at SMK Negeri 1 Bantul in the 2019/2020 academic year. The Collecting data technique in this study is using written tests, observations, field notes, and documentation. The data analisys of action research technique used quantitative descriptive techniques. The results of the research indicate that the application of the demonstration method can increase creativity and learning outcomes of class XI BDP 1 SMK N 1 Bantul in Online Business subjects for the 2019/2020 academic year. The application of the demonstration method is in accordance with the lesson plan, creativity and student learning outcomes have increased in each cycle. It is proven by the increase of value in the research instrument. In the observation sheet of leraning creativity, it was obtained a value of 48.42 with a lack of criteria at the initial observation stage, in the first cycle the value increased to 58.55 with sufficient criteria and in the second cycle the value was 67.53 with good criteria. In addition, classical completeness in the evaluation of learning outcomes also increased, at the initial evaluation classical completeness was $31.03 \%$, in cycle I increased to $48.28 \%$ and in cycle II classical completeness became $72.41 \%$.
\end{abstract}

Keywords: creativity, student learning outcomes and demonstration methods 


\section{Pendahuluan}

Pendidikan menengah bertujuan untuk mempertajam keilmuan setelah siswa menyelesaikan tahapan yang dimulai pada pendidikan dasar. Pendidikan menengah juga bertujuan mempersiapkan siswa menjadi bagian dari warga masyarakat yang mampu menjalin hubungan timbal balik dalam lingkungan sosial dan budaya. Pendidikan menengah menyiapkan siswa untuk mampu terjun di perusahaan atau memilih untuk kuliah di perguruan tinggi sesuai jurusan yang diinginkan.

Pendidikan di SMK dikembangkan untuk memenuhi kebutuhan tenaga kerja di perusahaan level regional, nasioanl maupun internasional. Pendidikan di SMK juga bertujuan untuk meningkatkan kemampuan siswa dalam berwirausaha bahkan tidak menutup kemungkinan untuk membekali siswa yang hendak melanjutkan pendidikan di perguruan tinggi. Tujuan umum pendidikan di SMK yaitu meningkatkan kecerdasan pengetahuan, keterampilan dan sosial. Sedangkan tujuan khusus yaitu menyiapkan siswa SMK untuk lebih siap bekerja baik di perusahaan maupun berwirausaha mandiri dan atau kuliah di perguruan tinggi sesuai minat dan jurusan yang diambil.

Siswa SMK memiliki kelebihan yaitu menguasai keterampilan dibidang yang diminati. Kegiatan pembelajaran didominasi oleh kegiatan praktek sehingga mengasah keterampilan siswa. Pada tingkat selanjutnya siswa SMK terjun langsung di dunia kerja dalam kegiatan praktek kerja lapangan (PKL). PKL sangat penting bagi siswa SMK karena siswa akan mengetahui secara langsung dunia kerja dan hal-hal yang akan dihadapi setelah lulus dari SMK. Siswa SMK tentu lebih siap masuk ke dunia kerja maupun membuka lapangan usaha sendiri atau berwirausaha. Dalam berwirausaha siswa SMK memiliki kemampuan manajemen yang baik karena lebih mendalami keahlian dan ide untuk memanfaatkan kemampuan yang dimiliki.

Peran sekolah menjadi kunci bagi keberhasilan siswa SMK dalam menuntaskan pendidikan di jenjang menengah. Sekolah memiliki peran penting untuk menyiapkan siswa SMK menjadi generasi yang handal, kompetitif dan bertanggung jawab. Proses pembelajaran di sekolah memegang peran utama dalam membentuk siswa SMK menjadi lulusan yang berjiwa mandiri, kreatif, inovatif dan pantang menyerah. Sekolah menyiapkan siswa SMK yang berorientasi pada dunia kerja serta siap menjawab tantangan jaman yang serba digital.
Upaya peningkatan mutu pendidikan di sekolah antara lain merumuskan program sekolah dengan menitikberatkan pada pengembangan keahlian siswa dan menambah wawasan dan keterampilan guru dalam melaksanakan kegiatan belajar mengajar yang lebih memberi makna bagi siswa. Bentuk nyata dari meningkatnya kompetensi guru dalam mengajar adalah terwujudnya kegiatan belajar mengajar yang menarik dan menuntut siswa untuk aktif dan kreatif dalam kegiatan pembelajaran. Inovasi dan kreativitas dalam memilih metode pembelajaran tentu sangat menentukan berhasilnya proses belajar mengajar bagi guru dan menghasilkan pembelajaran yang lebih bermakna bagi siswa.

Kegiatan belajar mengajar yang aktif, kreatif dan menggembirakan dapat mendorong siswa lebih mudah dalam memahami materi pembelajaran. Kegiatan pembelajaran ini juga akan mendorong peningkatan kreativitas dan hasil belajar siswa. Hal ini harus didukung dengan sarana dari sekolah untuk mewujudkan iklim belajar yang kondusif.

Pemilihan metode yang tepat dalam kegiatan pembelajaran dapat mendorong pelaksanaan kegiatan pembelajaran lebih kreatif dan menyenangkan. Hal ini akan menarik minat dan kreativitas siswa dalam proses pembelajaran. Penggunaan metode pembelajaran yang tepat juga dapat menyiapkan siswa menghadapi era pembelajaran abad 21 yang penuh tantangan dan dinamika. Terdapat empat kompetensi yang harus dikembangkan dalam pembelajaran abad 21 yaitu kemampuan untuk berpikir kritis (critical thinking), kemampuan dalam bekerja sama yang baik, (collaboration), kemampuan dalam berkomunikasi (communication) serta memiliki kreativitas tinggi (creativity).

Kreativitas tentunya memegang peranan penting dalam proses manusia menghadapi kemajuan jaman. Siswa SMK seharusnya memegang peranan penting dalam hal ini karena sudah memiliki keahlian dan sudah dibekali kreativitas tinggi sehingga akan menghasilkan ide yang cemerlang. Namun, keadaan di lapangan masih cukup jauh dari kondisi ideal yang diharapkan. Pembelajaran di kelas cenderung masih monoton dan tidak memancing kreativitas siswa. Proses pembelajaran yang kurang menarik berdampak pada pasifnya siswa dalam kegiatan pembelajaran. Siswa yang pasif tidak tertantang untuk mempelajari materi secara lebih mendalam bahkan justru merasa bosan. Dampak dari pasifnya siswa dalam kegiatan pembelajaran akan menyebabkan siswa tidak 
memahami materi pembelajaran yang sudah diberikan.

Berdasarkan data hasil belajar SMK N 1 Bantul diperoleh hasil bahwa pencapaian hasil belajar siswa kelas XI BPD 1 SMK N 1 Bantul dengan jumlah 29 siswa belum optimal. Hal tersebut dibuktikan dengan nilai rata-rata kelas XI BDP 1 lebih rendah dibandingkan nilai ratarata kompetensi keahlian lain di SMK N 1 Bantul. Temuan ini merupakan tantangan bagi guru yang mengajar di keals XI BPD 1 untuk memperbaiki proses pembelajaran agar siswa memperoleh nilai yang optimal.

Berdasarkan hasil pengamatan terhadap kondisi siswa pada saat proses pembelajaran Bisnis Online di kelas XI BDP 1 SMK N 1 Bantul, nampak bahwa kreativitas belajar pada siswa dalam mengikuti proses pembelajaran belum optimal. Sebagai contoh pada saat pembelajaran di laboratorium komputer, siswa hanya mengikuti apa yang ditugaskan guru. Siswa menyimak dan hanya mendengarkan. Ketika guru menyampaikan materi siswa kurang tertarik untuk mendalami lebih lanjut dan cenderung pasif dalam melakukan eksplorasi materi yang diberikan. Siswa sebatas mencatat dan mempraktikkan instruksi yang diberikan oleh guru. Ketika guru meminta salah satu siswa sebagai perwakilan kelompok untuk maju ke depan kelas dan mempresentasikan hasil pekerjaannya, siswa tidak memiliki inisiatif maju ke depan. Guru harus menunjuk salah satu siswa dan siswa yang maju presentasi masih terlihat terpaksa.

Kreativitas dalam belajar belum terlihat dalam proses pembelajaran. Berdasarkan lembar observasi pra siklus dapat diperoleh skor 48.82 dengan kriteria kurang. Hal ini dikarenakan siswa hanya mencatat dan mengikuti instruksi dari guru, serta tidak mengeksplorasi materi yang diajarkan. Data yang diperoleh terkait hasil belajar juga belum optimal. Hal ini dapat dilihat dari observasi awal dimana ketuntasan klasikal hanya $31,03 \%$. Kurang aktifnya siswa dalam mengeksplorasi materi tentu menjadi penyebab nilai penilaian harian siswa tidak maksimal. Siswa hanya mempelajari materi yang diberikan guru dan tidak memperluas pengetahuannya. Hal ini berdampak pada nilai ketuntasan klasikal yang rendah. Berdasarkan kedua hal tersebut guru melakukan penelitian dalam rangka memperbaiki proses kegiatan belajar mengajar yang diharapkan mampu meningkatkan kreativitas siswa dalam belajar dan memperbaiki nilai penilaian harian yang merupakan hasil belajar siswa.
Guru yang baik harus mampu membawa kegiatan pembelajaran menjadi aktif, kreatif, inovatif dan menggembirakan serta memperluas pengalaman belajar siswa dan tidak hanya sekedar transfer pengetahuan. Guru harus membimbing dengan baik agar siswa memperoleh pengalaman pengalaman belajar yang bermakna. Dalam rangka mencapai tujuan tersebut, pemilihan metode pembelajaran tentu sangat berpengaruh. Dengan penggunaan metode yang tepat maka kegiatan pembelajaran akan berbobot dan memberikan siswa pengalaman belajar yang bermutu.

Metode pembelajaran yang digunakan guru seharusnya metode pembelajaran yang efektif, menyenangkan dan meningkatkan kreativitas siswa dalam proses pembelajaran. Dengan kegiatan demikian siswa memperoleh pengalaman belajar yang aktif dan kreatif dan secara tidak langsung memancing siswa untuk mengeksplorasi materi yang diberikan oleh guru. Pemilihan metode pembelajaran yang sesuai mampu meningkatkan nilai pengetahuan dan keterampilan siswa.

Pada tingkat SMK, mata pelajaran produktif membedakan kompetensi keahlian satu dengan yang lainnya. Bisnis Online merupakan salah satu mata pelajaran wajib pada Kompetensi Keahlian Bisnis Daring dan Pemasaran. Mata pelajaran Bisnis Online sangat penting dalam kurikulum kelompok mata pelajaran produktif. Bisnis Online mengajarkan kepada siswa untuk handal dalam ilmu pemasaran online maupun menjalankan bisnis online atau bisnis dalam jaringan.

Metode demonstrasi digunakan untuk menyajikan materi dengan cara memperagakan baik proses maupun hasil belajar oleh guru kepada siswa yang relevan dengan materi yang diajarkan. Metode ini mempermudah guru dalam menjelaskan materi pembelajaran karena memperlihatkan langsung kepada siswa tentang proses mengerjakan sesuatu sampai menghasilkan produk atau capaian. Dengan mengamati secara langsung siswa lebih cepat memahami materi pembelajaran. Siswa juga ikut melakukan demonstrasi dan mempraktekkan secara langsung di depan kelas.

Metode demonstrasi memilki kelebihan antara lain mampu memusatkan perhatian siswa untuk fokus pada penjelasan guru. Siswa tertarik dan ikut terlibat dalam pembelajaran secara aktif. Guru mampu mengarahkan siswa untuk berpikir sama selama pembelajaran di kelas. Metode demontrasi memberikan gambaran jelas bagi siswa sesuai hasil pengamatan dan secara langsung dapat menjawab persoalan yang muncul di benak siswa. Metode demonstrasi 
diharapkan mampu memancing kreativitas siswa selama proses pembelajaran.

Kreativitas merupakan daya untuk menciptakan sesuatu yang berbeda dan baru, tetapi dapat juga merupakan perpaduan baru dari hal-hal yang sudah ada (Satiadarma dan Waruwu, 2003: 108). Pengertian lain dari kreativitas menurut Munandar adalah kemampuan untuk menciptakan gabungan unsur yang baru berdasarkan unsur yang sudah ada, adanya kemampuan untuk memberikan berbagai kemungkinan jawaban terhadap suatu permasalahan, dengan tetap menekankan pada mutu, ketepatan dan keberagaman reaksi yang merefleksikan kemudahan, fleksibikitas dan kemurnian dalam berfikir serta kemampuan untuk mendeskripsikan suatu pemikiran (Sukmadinata, 2004: 104)

Keberhasilan siswa dalam memahami materi pembelajaran dapat dilihat dari kreativitas yang tinggi dalam kegiatan pembelajaran. Kreativitas belajar mempunyai andil penting untuk meraih keberhasilan dalam pembelajaran. Menurut yang disampaikan Usman (1993: 11) siswa dengan kreativitas tinggi dalam pembelajaran akan berdampak memiliki tingkat kreativitas yang tinggi pula dalam berbagai kegiatan. Siswa dengan kreativitas tinggi akan memiliki strategi dalam memecahkan berbagai persoalan yang diberikan, siswa akan percaya diri dalam menghadapi resiko meskipun sulit, baik secara destruktif maupun konstruktif. Siswa yang kreatif akan lebih nyaman untuk bekerja sendiri dan lebih percaya diri pada kemampuannya.

Nilai hasil belajar menjadi bagian penting di dalam kegiatan pembelajaran. Hal ini sebagai tolak ukur bagi guru terkait keberhasilan suatu proses pembelajaran. Nilai hasil belajar dapat didefinisikan sebagai pergantian tingkah laku siswa yang terdiri dari nilai sikap (afektif), nilai pengetahuan (kognitif), dan nilai keterampilan (psikomotorik) (Nana Sudjana, 2009: 3).

Definisi lain hasil belajar menyebutkan bahwa nilai hasil belajar sebagai hasil dari interaksi kegiatan pembelajaran yang melibatkan siswa dengan guru. Guru mengawali kegiatan pembelajaran dengan pendahuluan, kegiatan inti lalu penutup. Pada akhir rangkaian pertemuan guru melaksanakan evaluasi. Evaluasi merupakan kegiatan bagi guru untuk mengetahui sejauh mana pemahaman siswa terhadap materi pembelajaran. Hasil evaluasi digunakan guru sebagai alat evaluasi pembelajaran. Sesuai rencana penilaian yang telah disusun guru pada awal tahun pelajaran, maka ketercapaian siswa berdasarkan nilai Kriteria Ketuntasan Minimal (KKM) dapat dipetakan dengan tepat.
Sedangkan bagi siswa hasil evaluasi merupakan indikator berakhirnya proses belajar yang diwujudkan dalam bentuk angka (Dimyati dan Mudjijono, 2006: 3 - 4)

Faktor yang mempengaruhi kegiatan belajar siswa ada 2 yaitu faktor dari dalam (intern) dan faktor dari luar (ekstern). Faktor intern merupakan faktor dari dalam diri seorang seperti motivasi dalam belajar, sedangkan fkator ekstern adalah faktor yang berasal dari luar individu tersebut, sebagai contoh faktor keluarga maupun lingkungan. Kedua faktor tersebut dapat menjadi pendukung maupun penghambat belajar siswa (Riyani, 2012).

Pencapaian hasil kegiatan belajar siswa dapat diukur menggunakan tes evaluasi baik itu ulangan, ujian tengah semester, ulangan akhir semester mapun ujian sekolah. Alat ukur untuk menilai hasil belajar dapat menggunakan tes tulis maupun tes lisan. Penilaian hasil belajar dapat didefinisikan sebagai seperangkat tes untuk mengukur tingkat pemahaman siswa setelah selesai mengikuti proses pembelajaran sesuai alokasi waktu yang ditentukan. Tes hasil belajar yang disusun sedemikian rupa harus mampu mengukur hasil belajar siswa setelah selesai mengikuti rangkaian proses pembelajaran. Tes evaluasi hasil belajar sebagai instrumen untuk mengukur ketercapaian indikator belajar siswa setelah mengikuti rangkaian kegiatan pembelajaran yang sesuai dengan prosedur yang sudah dirumuskan terlebih dahulu (Suharsimi Arikunto, 2003: 53).

Metode demonstrasi merupakan bagian dari pembelajaran kooperatif learning. Metode ini memperagakan suatu benda dengan cara tertentu bersamaan dengan penjelasan secara lsian oleh seorang guru. Metode demonstrasi dapat dilakukan dengan cara mempresentasikan proses pembelajaran, alat peraga tertentu di depan kelas. Dalam metode demonstrasi guru dapat menampilkan pembelajaran yang lebih nyata dengan strategi pembelajaran yang tepat (Sanjaya W, 2006: 152).

Rumusan masalah dari kegiatan penelitian ini yaitu; apakah metode demonstrasi dapat meningkatkan kreativitas dan hasil belajar siswa kelas XI BDP 1 SMKN 1 Bantul tahun pelajaran 2019/2020 pada mata pelajaran Bisnis Online?

Pelaksanaan penelitian tindakan kelas ini mempunyai tujuan umum untuk mengetahui keefektifan metode demonstrasi dalam meningkatkan kreativitas dan hasil belajar. Tujuan khusus penelitan ini yaitu meningkatkan kreativitas dan hasil belajar Bisnis Online siswa kelas XI BDP 1 SMK N 1 Bantul setelah mengikuti pembelajaran dengan metode demonstrasi. 
Kegiatan penelitian ini diharapkan membawa manfaat bagi ilmu pengetahuan, yaitu bahwa penggunaan metode demonstrasi dalam kegiatan belajar mengajar mampu menumbuhkan kreativitas siswa dalam mempelajari mata pelajaran Bisnis Online dan meningkatkan nilai hasil belajar siswa. Sedangkan manfaat bagi guru yaitu metode demonstrasi mampu menciptakan kegiatan belajar mengajar yang efektif dan menggembirakan serta siswa aktif dan kreatif dalam proses pembelajaran. Dengan demikian kreativitas dan nilai hasil belajar siswa dapat meningkat.

\section{Metode Penelitian}

Penelitian ini merupakan penelitian deskriptif kuantitatif yang berbentuk Penelitian Tindakan Kelas (PTK) dengan tujuan meningkatkan mutu pembelajaran di sekolah. Kegiatan penelitian ini dilakukan melalui 2 siklus dan pada tiap siklus terdiri dari 4 pertemuan. Penelitian dimulai dengan terlebih dahulu melakukan identifikasi permasalahan dalam kegiatan belajar mengajar.

Penelitian ini dilakukan pada semester gasal Tahun Pelajaran 2019/2020. Waktu yang digunaan dalam penelitian ini kurang lebih selama 3 bulan yang dimulai bulan Juli 2019 sampai dengan bulan September 2019. Materi pembelajaran disesuaikan dengan jadwal pelajaran sekolah. Lokasi penelitian ini di SMK N 1 Bantul yang beralamat di dusun Dukuh kelurahan Sabdodadi, kecamatan Bantul, Daerah Istimewa Yogyakarta.

Subjek Penelitian tindakan kelas ini adalah siswa kelas XI BDP 1 SMK N 1 Bantul yang terdiri dari 29 orang dengan komposisi 24 siswa perempuan dan 5 siswa laki-laki. Alasan ditetapkan sebagai subjek penelitian karena masih rendahnya nilai rata-rata kompetensi keahlian di kelas XI BDP 1 dibanding keahlian lainnya di SMK N 1 Bantul.

Kegiatan penelitian tindakan kelas ini mengacu pada model spiral dengan tahapan pada tiap siklusnya terkait dengan pelaksanaan siklus lain. Tiap siklus penelitian ini terdiri dari 4 tahapan, yaitu perencanaan, tindakan, pengamatan dan refleksi yang mengutip Kemmis dan Tagart (Rochiati wiriatmadja, 2008: 66-67). Rencana Pelaksanaan Pembelajaran (RPP) yang akan digunakan selama penelitian disusun pada tahap perencanaan. RPP yang disusun memuat 13 komponen sesuai Peraturan Mendikbud Nomor 22 Tahun 2016 Tentang Standar Proses.

Pada RPP rumusan Kompetensi Dasar (KD) dijabarkan menjadi beberapa Indikator
Pencapaian Kompetensi (IPK). IPK yang disusun guru dibedakan antara aspek pengetahuan dan aspek keterampilan. Selanjutnya IPK digunakan untuk menyusun tujuan pembelajaran pada tiap pertemuan yang dilengkapi dengan ABCD (Audience, Behaviour, Condition dan Degree). Tiap pertemuan dalam RPP terdiri dari kegiatan pendahuluan yang berupa apersepsi dan motivasi, inti pembelajaran dan kegiatan penutup. Metode demonstrasi dilaksanakan pada inti pembelajaran. Setelah menyusun RPP guru menyusun lembar observasi yang terdiri dari lembar observasi siswa, observasi aktivitas guru dan siswa, catatan lapangan, kisi-kisi soal dan evaluasi, tugas kelompok dan tugas mandiri siswa. Kelengkapan penelitian dirancang pada proses perencanaan selama 2 minggu.

Setelah menyelesaikan penyusunan kelengkapan pada tahap perencanaan maka kegiatan selanjutnya adalah melaksanakan kegiatan pembelajaran sesuai dengan rencana pelaksanaan pembelajaran (RPP) yang telah disusun.

Indikator kreativitas belajar siswa menurut Munandar seperti yang dikutip Hamzah B. Uno dan Nurdin Mohamad (2011) antara lain 1) siswa mempunyai rasa ingin tahu yang tinggi, 2) siswa sering menanyakan suatu permasalahan yang berbobot, 3) siswa banyak memberikan ide dan usulan, 4) siswa mampu memberikan jawaban yang insidental dan percaya diri, 5) siswa memiliki rasa seni yang tinggi, 6) siswa memiliki prinsip dalam terhadap pendapatnya sendiri, 7) siswa memiliki rasa humor yang besar 8) siswa mampu berimaginasi dengan kuat, 9) siswa mampu memberikan gagasan yang original 10) siswa mampu bekerja mandiri, 11) siswa senang bereksperimen tentang hal-hal baru 12) siswa dapat mengembangkan suatu ide yang baru.

Selama guru mengajar, kegiatan pengamatan dilaksanakan oleh kolaborator terkait pelaksanaan pembelajaran di kelas. Kolabolator melakukan pengamatan dari awal pendahuluan sampai pada kegiatan penutup. Kolaborator mencermati tiap tahapan yang dilalui guru dan siswa serta menuliskan hasilnya pada lembar pengamatan. Guru dan kolaborator mendiskusikan catatan lapangan. Setelah kolaborator mendiskusikan dengan guru mta pelajaran, maka tahap terakhir adalah refleksi. Pada kegiatan ini dilakukan analisa terhadap rangkaian kegiatan yang telah dilakukan. Hasil analisa kegiatan selanjutnya digunakan untuk Menyusun perencanaan untuk siklus berikutnya. Penelitian ini dilakasanakan dalam 2 siklus dengan setiap siklus terdiri dari 4 pertemuan. 
Data yang digunakan dalam penelitian tindakan kelas ini terdiri dari 2 data yaitu data primer dan data pendukung. Data primer berupa lembar penilaian kognitif siswa dan hasil belaajr siswa sebelum tindakan dilaksanakan dan data hasil pengamatan tentang kretivitas siswa ketika terlibat dalam proses pembelajaran. Data terkait hasil belajar siswa diperoleh dari penilaian harian berupa tes tertulis. Capaian kreativitas belajar dieproleh melalui observasi yang dilakukan oleh kolaborator. Data pendukung berupa kondisi dan catatan lapangan yang diberikan oleh kolaborator terdiri dari lembar telaah Rencana Pelaksanaan Pembelajaran (RPP), lembar telaah aktifitas guru dan siswa serta dokumentasi kegiatan pembelajaran di dalam kelas.

Penggunaan teknik analisa data pada kegiatan penelitian ini dilakukan dengan cara membuat analisis peningkatan indikator keberhasilan dari kondisi pra siklus, tahap siklus I dan pada siklus II. Indikator keberhasilan dalam penelitian ini jika penilaian kreativitas secara klasikal sudah mencapai minimal baik yaitu 60, kategori secara rinci dipaparkan dalam tabel 1 berikut.

Tabel 1. Rata-Rata Kreativitas Belajar

\begin{tabular}{lc}
\hline \multicolumn{1}{c}{ Rentang Nilai } & Kategori \\
\hline $0 \leq$ rata-rata $<20$ & Kurang sekali \\
$20 \leq$ rata-rata $<40$ & Kurang \\
$40 \leq$ rata-rata $<60$ & Cukup \\
$60 \leq$ rata-rata $<80$ & Baik \\
$80 \leq$ rata-rata $<100$ & Baik sekali \\
\hline
\end{tabular}

Data kuantitif berupa hasil analisis hasil belajar untuk menghitung ketuntasan klasikal. Indikator keberhasilan dari hasil belajar jika ketuntasan klasikalnya minimal $70 \%$ dengan kriteria ketuntasan minimal 75 . Hasil analisis tersebut digunakan untuk melihat kenaikan hasil belajar siswa dari konsidi pra siklus, siklus I dan siklus II. Sedangkan hasil pengamatan kreativitas siswa pada lembar observasi dituangkan dalam bentuk tabulasi dan dilakukan analisis untuk melihat kenaikan segi kreativitas siswa pada tiap siklus.

\section{Hasil dan Pembahasan}

Penelitian tindakan kelas ini dilaksanakan dalam 2 siklus dimana tiap siklusnya terdiri dari 4 kali pertemuan. Berdasarkan observasi kegiatan pembelajaran di dalam kelas diperoleh catatan pada tahap pendahuluan guru mampu melaksanakan pembelajaran sesuai dengan yang tertulis di RPP. Guru melaksanakan kegiatan pendahuluan yang dimulai dari absensi siswa, menanyakan kabar dan mengecek kesiapan siswa dalam mengikuti pelajaran hari itu. Guru menyampaikan apersepsi dan motibvasi siswa dalam mempelajarai materi yang akan diberikan. Guru membantu siswa mengingat kembali materi yang telah dipelajari pada pertemuan sebelumnya. Guru menitikberatkan pada tujuan pembelajaran yang akan dicapai pada pertemuan hari tersebut.

Pada kegiatan inti guru memberikan penjelasan terkait materi yang diberikan lalu mempraktekkan di depan kelas. Siswa mengamati dan dipersilahkan untuk bertanya apabila ada hal yang dirasa belum paham. Guru menjawab dengan baik dan memastikan siswa sudah paham. Selanjutnya guru membagi siswa menjadi beberapa kelompok. Tiap kelompok mempelajari terlebih dahulu materi yang telah ditentukan oleh guru selama waku yang telah disepakati. Siswa diperbolehkan untuk menggunakan sumber belajar sebanyakbanyaknya baik dari buku paket maupun lingkungan sekitar Setelah selesai mempelajari materi, selanjutnya perwakilan tiap kelompok melakukan presentasi di depan kelas serta memberi contoh kepada siswa yang lain.

Pada tahap ini ditemukan catatan penting bahwa guru masih harus lebih banyak membimbing siswa. Hal ini dikarenakan penguasaan materi oleh siswa belum maksimal. Siswa masih belum mampu untuk belajar secara mandiri hingga tuntas. Siswa sebatas membaca materi dan tidak mengeksplorasi lebih lanjut materi yang diberikan oleh guru.

Keaktifan siswa dalam proses pembelajaran belum terlihat optimal. Hal ini ditandai dengan belum adanya keinginan mandiri dari siswa untuk maju mempresentasikan hasil diskusi kelompok di depan teman-temannnya. Pada tahap ini guru harus menunjuk seorang perwakilan kelompok untuk melakukan presentasi. Ketika melakukan presentasi siswa sebatas memaparkan materi standar yang sama dengan buku paket. Siswa belum mampu memberikan pemaparan yang lebih luas.

Pada tahapan siklus I mulai muncul temuan baru oleh kolaborator. Guru mulai mengajar menggunakan metode demonstrasi di depan kelas. Siswa mulai tertarik dan mempelajari materi diskusi dengan antusias. Hal ini dikarenakan siswa tertantang untuk memahami dengan betul materi yang diberikan guru agar dapat mempresentasikan dengan baik di depan kelas. Siswa mulai saling memberikan pendapat di dalam kelompok diskusi. Hal ini semakin memperluas wawasan mereka terkait materi yang dibagikan oleh guru. 
Pada tahap diskusi guru berkeliling untuk memandu jalannya diskusi dan menjawab pertanyaan dari siswa apabila diperlukan. Guru mulai membuka sesi presentasi. Siswa antusias ingin mempresentasikan di depan kelas dan tidak perlu ditunjuk oleh guru. Siswa mempresentasikan materi diskusi dengan lancar dan menggunakan bahasa yang santun. Ketika presentasi siswa selesai maka guru membuka forum tanya jawab. Siswa dari kelompok lain memberikan pertanyaan dan dijawab dengan baik dan runtun oleh siswa yang melakukan presentasi di depan kelas. Siswa dari kelompok lain diperbolehkan menambah penjelasan sehingga terjadi diskusi kelas yang baik dan berbobot.

Berdasarkan data hasil observasi oleh kolaborator diperoleh nilai kreativitas belajar materi Bisnis Online pada siklus I mencapai 58,55 dengan kriteria cukup. Hal ini tentunya mengalami peningkatan dari data yang diperoleh pada observasi awal yaitu 48,42 dengan kriteria kurang.

Pada kegiatan di kelas terlihat bahwa siswa semakin semangat dan terpacu ketika dihadapkan pada tugas membuat slide presentasi dan tampil di depan kelas. Siswa mempelajari terlebih dahulu materi yang akan dipresentasikan. Siswa mulai memperluas wawasan dnegan mempelajari berbagai sumber belajar. Siswa menyiapkan jawaban apabila ada teman yang bertanya. Siswa tampil untuk mendemonstrasikan materi yang telah dipelajari dengan sebaik-baiknya dengan bahasa yang santun dan intonasi bicara yang baik. Siswa yang lain menyimak dan apabila ada hal yang hendak ditanyakan atau dijadikan materi diskusi maka akan disampaikan pada sesi tanya jawab. Siswa menjawab pertanyaan teman dengan runtut dan percaya diri. Pada sesi ini siswa dari kelompok lain diperbolehkan untuk memberi masukan. Kegiatan presentasi berjalan dengan baik dan situasi kelas menjadi kondusif.

Peningkatan hasil belajar dengan menggunakan metode demonstrasi telah terbukti signifikan pada mata pelajaran aircraft component turning. Siswa dapat mengamati secara langsung proses kerja mesin melalui metode demontrasi proses pembelajaran dapat lebih riil (Kadarisman dkk, 2018: 163). Sejalan dengan penelitian tersebut, penelitian yang dilakukan oleh Aris Purwantinah juga terbukti bahwa metode demontrasi dapat meningkatkan kemampuan siswa dalam melakukan langkahlangkah stock opname sehingga hasil belajar juga akan meningkat secara signifikan (Purwantinah, 2020: 28)
Hasil evaluasi belajar dengan soal yang dibuat berdasarkan kisi-kisi untuk mengukur nilai belajar siswa yang dilakukan pada siklus I masih di bawah target yaitu ketuntasan maksimal $48,28 \%$. Namun demikian nilai ini tetap mengalami peningkatan dibandingkan pada observasi dengan nilai ketuntasan maksimal 31,03\%. Hal ini dikarenakan siswa masih mengikuti kegiatan pembelajaran yang monoton dan tidak menarik. Dampaknya siswa kurang antusias dalam memahami materi yang diberikan guru dan tidak terpacu mengeksplorasi kembali.

Data observasi kreativitas siswa dan evaluasi hasil belajar pada siklus I menunjukkan bahwa langkah pembelajaran menggunakan model demosntrasi sudah sesuai dengan sintak pada RPP yang telah disusun dan kemampuan siswa dalam memahami dan menindaklanjuti perintah dari guru selama proses pembelajaran meningkat. Hasil analisis data terlihat adanya peningkatan kreativitas belajar siswa selama mengikuti proses pembelajaran baik ketika mempelajari materi maupun ketika presentasi di depan kelas. Sementara itu hasil analisis evaluasi hasil belajar menunjukkan adanya peningkatan nilai siswa dan nilai kreativitas belajar siswa pada siklus I menunjukkan angka 58,55 hal ini masih berada pada kategori cukup sedangkan hasil belajar klasikal pada siklus I mencapai ketuntasan sebesar 48,28\%.

Berdasarkan hasil yang diperoleh pada siklus I maka kegiatan penelitian ini perlu dilanjutkan ke siklus II. Hal ini karena nilai ratarata kreativitas dan ketuntasan klasikal belum memenuhi standar yang telah ditetapkan pada indikator keberhasilan.

Berdasarkan kegiatan evaluasi dan refleksi pada siklus I diperoleh faktor penghambat dalam kegiatan pembelajaran. Hasil observasi kegiatan di siklus II menunjukkan bahwa kegiatan pembelajaran dengan model demonstrasi sesuai dengan RPP yang disusun. Jika pada siklus I guru cukup kewalahan dalam membimbing kelompok siswa melakukan demonstrasi. Namun pada siklus II siswa secara mandiri membaca lembar kerja, mencari informasi di buku maupun di internet sehingga siswa tidak merasa bingung dengan materi yang diberikan.

Berdasarkan data hasil observasi dapat dilihat bahwa kreativitas belajar siswa dari siklus I ke siklus II mengalami kenaikan yaitu 67,73 dengan kriteria baik. Fakta lain di lapangan menunjukkan bahwa pada kegiatan pembelajaran siswa semakin baik dalam menjelaskan materi pembelajaran dengan cara demonstrasi di depan kelas. Siswa menjelaskan 
materi dengan bahasa yang runtut, jelas dan mudah dimengerti oleh siswa lain.

Pada siklus II nilai hasil belajar yang diperoleh sudah mencapai terget yaitu ketuntasan klasikal mencapai $72,41 \%$. Guru mulai membiasakan siswa dalam menyelesaikan soal-soal dalam penugasan maupun penilaian harian dengan kemampuan berpikir tingkat tinggi. Berdasarkan hasil observasi pada siklus II diperoleh bahwa langkah pembelajaran dengan menggunakan metode demonstrasi telah sesuai dengan RPP yang digunakan pada kegiatan pembelajaran. Guru melaksanakan kegiatan pendahulan dengan lengkap, kegiatan inti dengan dan penutup dengan baik dan runtut. Kemampuan siswa dalam memahami instruksi guru dan lembar kerja siswa menunjukkan peningkatan. Siswa terbiasa membaca lembar kerja sebelum melakukan kegiatan demosntrasi di depan kelas dan mempelajari materi secara mendalam sebagai bekal melakukan presentasi di depan kelas. Sementara itu kreativitas belajar siswa sudah di atas indikator pencapaian dan peningkatan ketuntasan klasikal siswa dalam menyelesaikan soal sesuai kisi-kisi.

Berdasarkan hasil yang diperoleh pada siklus II yang terdiri dari nilai rata-rata kreativitas dan nilai hasil belajar siswa yang telah berada di atas indikator keberhasilan maka kegiatan penelitian ini berhenti sampai pada siklus II. Kegiatan penelitian ini dilaksanakan dalam dua siklus dengan tiap siklu terdiri dari 4 pertemuan. Penelitian ini digunakan untuk mengetahui upaya dalam meningkatkan kreativitas dan hasil belajar siswa kelas XI BDP 1 SMK N 1 Bantul pada mata pelajaran Bisnis Online dengan metode demonstrasi. Data hasil observasi dirangkum dalam tabel 2 di bawah ini.

Tabel 2. Hasil Analisis kreativitas siswa antar siklus

\begin{tabular}{lccc}
\hline \multicolumn{1}{c}{ Tahap } & $\begin{array}{c}\text { Total } \\
\text { Skor }\end{array}$ & $\begin{array}{c}\text { Nilai } \\
\text { Rata-Rata }\end{array}$ & Kriteria \\
\hline Observasi & 675 & 48,42 & Kurang \\
awal & & & \\
Siklus I & 815 & 58,55 & Cukup \\
Siklus II & 940 & 67,53 & Baik \\
\hline
\end{tabular}

Dengan mengamati hasil analisis pada tabel 2 terlihat bahwa hasil observasi pada kegiatan penelitian ini nampak ada peningkatan kreativitas belajar siswa pada tiap tahapnya. Tahap observasi awal nilai kreativitas siswa berada pada angka 48,42 dengan kriteria kurang. Pada siklus I mengamali peningkatan menjadi 58,55 dengan kriteria cukup dan siklus II peningkatannya menjadi 67,53 dengan kriteria baik. Dengan demikian penggunaan metode Demonstrasi membawa pengaruh baik di dalam proses pembelajaran.

Sedangkan data hasil belajar siswa sesuai data observasi pada penelitian ini ditampilkan pada tabel 3 berikut.

Tabel 3. Analsisi Hasil Belajar Siswa Antar Siklus

\begin{tabular}{lccc}
\hline Tahap & $\begin{array}{c}\text { Jumlah } \\
\text { Siswa } \\
\text { Tuntas }\end{array}$ & $\begin{array}{c}\text { Jumlah } \\
\text { Siswa } \\
\text { Tidak } \\
\text { Tuntas }\end{array}$ & $\begin{array}{c}\text { Ketuntasan } \\
\text { Klasikal }\end{array}$ \\
\hline Observasi & 9 & 20 & $31,03 \%$ \\
awal & 13 & 16 & $48,28 \%$ \\
Siklus I & 13 & 8 & $72,41 \%$ \\
Siklus II & 21 & \\
\hline
\end{tabular}

Berdasarkan tabel tersebut diperoleh bahwa hasil belajar pada tiap tahap pada kegiatan penelitian ini mengalami peningkatan. Pada kegiatan observasi awal masih rendah yaitu sebesar 31,03\%. Pada tahap siklus I ketuntasan klasikal mengalami peningkatan menjadi 48,28\% dan pada tahap siklus II ketuntasan ini naik menjadi $72,41 \%$.

Dari tabel 1 dan 2 yang telah disajikan di atas membuktikan bahwa metode demonstrasi merupakan salah satu metode pembelajaran yang tepat untuk digunakan dalam mata pelajaran Bisnis Online. Metode ini difokuskan pada aktivitas siswa untuk mempelajari, mencoba, dan memberikan contoh kepada teman-teman satu kelas melalui kegiatan praktek di depan kelas. Metode ini akan merangsang siswa untuk terus belajar sehingga memacu semangat untuk lebih menguasai materi yang akan disampaikan.

\section{Simpulan dan Saran}

Kesimpulan dari kegiatan Penelitian Tindakan kelas dengan judul "Peningkatan Kreativitas dan Hasil belajar Bisnis Online Melalui Metode Demonstrasi" secara kolaboratif antara peneliti dan guru pengamat/observer pada pelajaran Bisnis Online kelas XI BDP 1 SMK N 1 Bantul Tahun Pelajaran 2019/2020 dapat disimpulkan bahwa kegiatan pembelajaran menggunakan metode demonstrasi dapat meningkatkan kreativitas belajar pada mata pelajaran Bisnis Online kelas XI BDP 1 SMK N 1 Bantul tahun Pelajaran 2019/2020.

Hasil penelitian membuktikan bahwa penggunaan metode demonstrasi mampu meningkatkan kreativitas siswa dalam mempelajari Bisnis Online. Pembelajaran menggunakan metode demonstrasi juga mampu meningkatkan nilai hasil belajar pada pelajaran Bisnis Online kelas XI BDP 1 SMK N 1 Bantul 
Tahun Pelajaran 2019/2020. Hal ini membuktikan bahwa metode demonstrasi membantu siswa untuk memahami pelajaran Bisnis Online dengan baik.

Peningkatan kreativitas dan hasil belajar siswa pada pelajaran Bisnis Online kelas XI BDP 1 SMK N 1 Bantul Tahun Pelajaran 2019/2020 terlihat dari indikator hasil tabulasi pada lembar observasi penelitian menunjukkan bahwa nilai rata-rata kreativitas siswa cenderung mengalami peningkatan. Pada observasi awal kreativitas siswa bernilai 48, 42, pada siklus I naik menjadi 58,55 dan pada siklus II menjadi 67,53. Hasil belajar siswa meningkat secara signifikan pada tiap tahap penelitian tindakan kelas. Pada observasi awal ketuntasan klasikal sebesar $31,03 \%$, pada siklus I sebesar $48,28 \%$ dan pada siklus II sebesar 72,41\%.

Penelitian Tindakan Kelas (PTK) dilaksanakan untuk memperbaiki proses dalam pembelajaran dan meningkatkan kreativitas belajar siswa serta hasil belajar berupa nilai pengetahuan dan keterampilan. Berdasarkan hasil kesimpulan peneliti memberikan saran bagi Kepala sekolah untuk dapat mendorong guru mengembangkan dan memilih metode pembelajaran yang cocok untuk digunakan di dalam kelas.

Kepala sekolah dapat menyusun program peningkatan kemampuan guru dalam mengajar, seperti kegiatan workshop atau lesson study sekolah. Dengan demikian iklim mengajar tepat guna mampu berkembang dengan baik di lingkungan sekolah. Bagi guru mata pelajaran Bisnis Online maupun guru mata pelajaran lain pada umumnya harus memilih metode yang tepat untuk mengajar dan lebih kreatif serta inovatif dalam proses pembelajaran di kelas.

Pemilihan metode yang sesuai dengan materi yang diajarkan sangat membantu siswa dalam memahami materi yang diberikan oleh guru. Dengan demikian proses pembelajaran akan berjalan lancar dan mencapai hasil maksimal. Bagi siswa dalam hal ini sebagai subjek kegiatan pembelajaran diharapkan mampu membiasakan diri menyampaikan pendapat dan pikirannya di dalam forum diskusi kelas dan berani untuk presentasi secara mandiri. Dengan pembiasaan yang baik maka lulusan SMK mampu memiliki kemampuan yang handal, kompetitif dan pantang menyerah.

\section{Daftar Pustaka}

Dimyati dan Mudjiono. (2006). Belajar dan Pembelajaran. Jakarta: PT Rineka Cipta.

Hamzah B. Uno \& Nurdin Mohamad. (2011). Belajar dengan Pendekatan Pailkem: pembelajaran aktif, inovatif, lingkungan, kreatif, menarik. Jakarta: Bumi Aksara.

Kadarisman, Deri E, dkk. (2018). Upaya Peningkatan Hasil Belajar Siswa Melalui Penerapan Metode Pembelajaran Demonstrasi pada Mata Pelajaran Aircraft Component Turning. Jurnal Mechanical Engineering Education, 5(2), 169-175.

https://ejournal.upi.edu/index.php/jmee/a rticle/view/15184

Purwantinah, Aris. (2020). Peningkatan Kemampuan Melakukan Langkah-Langkah Stock Opname Menggunakan Metode Demonstrasi. Ideguru: Jurnal Karya Ilmiah Guru, 5(2), 20-28.

https://doi.org/10.51169/ideguru.v5i2.124

Riyani, Y. (2012). Faktor-faktor yang mempengaruhi prestasi mahasiswa (Studi pada mahasiswa Jurusan Akuntansi Politeknik Negeri Pontianak). Jurnal EKSOS, 8, 19-25.

Rochiati Wiriaatmadja. (2008). Metode Penelitian Tindakan Kelas untuk Meningkatkan Kinerja Guru dan Dosen. Bandung: PT Remaja Rosdakarya.

Sanjaya, W. (2006). Strategi pembelajaran beorientasi standar proses pendidikan. Jakarta: Kencana Prenada Media Group.

Satiadarma, M.P. dan Waruwu, F.E. (2003). Mendidik Kecerdasan. Jakarta: Pustaka Populer Obor.

Suharsimi Arikunto. (2003). Dasar-dasar Evaluasi Belajar. Jakarta: Bumi Aksara. 